Port Econ J (2014) 13:195-216

DOI 10.1007/s10258-014-0106-6

ORIGINAL ARTICLE

\title{
Obsolescence and productivity
}

\author{
Fernando del Rio - Antonio Sampayo
}

Received: 27 May 2014 / Accepted: 7 December 2014 / Published online: 16 December 2014 (C) ISEG 2014

\begin{abstract}
The increase in the obsolescence of intangible capital caused by the adoption of new information technologies can play an important role in accounting for the productivity slowdown undergone by the US economy since 1974. To explore this hypothesis, we have developed a standard growth model with physical and intangible capital in which technical progress is equipment-specific. We assume that the obsolescence of intangible capital increases when the equipment-specific technical progress accelerates. The model is calibrated for the period 1957-1973 and the response of the economy to an increase in the rate of equipment-specific technical progress — as observed since 1974 - is simulated. We show that this setup can account for a large part of the post-1974 slowdown observed in productivity and in the Solow residual.
\end{abstract}

Keywords Obsolescence $\cdot$ Intangible capital $\cdot$ Equipment-specific technical progress $\cdot$ Productivity slowdown

JEL Classification $\mathrm{E} 23 \cdot \mathrm{O} 30 \cdot \mathrm{O} 47$

F. del Rio · A. Sampayo

Universidade de Santiago de Compostela, Santiago de Compostela, Spain

e-mail: fernando.delrio@usc.es

\section{A. Sampayo}

Departamento de Fundamentos da Análise Económica, Facultade de CC. Económicas

e Empresariais, Avda. Burgo das Nacións s/n, 15782, Santiago de Compostela, Spain

e-mail: ar.sampayo@usc.es 